\title{
A NOVEL VESICULAR APPROACH FOR TRANSDERMAL ADMINISTRATION OF ENALAPRIL MALEATE LOADED NANOPRONIOSOMAL GEL: FORMULATION, EX VIVO EVALUATION AND IN VIVO ANTIHYPERTENSIVE STUDY
}

\author{
M. SABAREESH ${ }^{*}$, J. P. YANADAIAH ${ }^{2}$, K. B. CHANDRA SEKHAR ${ }^{3}$
}

${ }^{1}$ Jawaharlal Nehru Technological University Anantapur, Ananthapuramu, Andhra Pradesh, India, ${ }^{2}$ Department of Pharmacognosy, Dr. K. V. Subba Reddy Institute of Pharmacy, Kurnool, Andhra Pradesh, India, ${ }^{3}$ Department of Chemistry, Krishna University, Machilipatnam, Andhra Pradesh, India

Email: sabareesh85@gmail.com

Received: 27 May 2020, Revised and Accepted: 20 Jul 2020

\section{ABSTRACT}

Objective: The objective of the study was to formulate and evaluate the nanoproniosomal gel of Enalapril maleate (EM) for the treatment of hypertension through the transdermal administration and to provide better bioavailability.

Methods: The nanoproniosomal gel of the EM was formulated by Lecithin, Cholesterol, Non-ionic surfactants using the Coacervation-phase separation method. The prepared nanoproniosomal gels were evaluated for $\mathrm{pH}$ and viscosity, vesicle size analysis, rate of spontaneity, entrapment efficiency, zeta potential, ex vivo skin permeation studies, skin irritation test, stability studies and in vivo antihypertensive studies.

Results: Physical characterization was found to be within acceptable limits. The ex vivo skin permeation studies showed the cumulative permeation of $58.75 \%$ to $89.72 \%$ through the albino rat skin in $24 \mathrm{~h}$ for all the formulations, which indicate the zero-order drug permeation with diffusion, non-fickian release. Among all formulations, EMNP7 was selected as best formulation because it showed better characteristics than other formulations in several aspects like physicochemical characterization, ex vivo skin permeation studies, permeation kinetics, and other evaluation parameters. The skin irritation study revealed that there was no irritation after topical application and it was found to be safer to use. The In vivo antihypertensive study revealed that the formulation of EMNP7 was successful to regress the rat blood pressure (BP) to normal values in experimental hypertensive rats.

Conclusion: The nanoproniosomal gel is an efficient transdermal therapeutic system for the delivery of EM for the treatment of hypertension. It is suitable for once a day controlled release formulation.

Keywords: Cholesterol, Enalapril maleate, Ex vivo Permeation studies, In vivo antihypertensive studies, Lecithin, Nonionic surfactants, Proniosomes, Skin irritation studies, Transdermal gel

(C) 2020 The Authors. Published by Innovare Academic Sciences Pvt Ltd. This is an open access article under the CC BY license (http://creativecommons.org/licenses/by/4.0/) DOI: http://dx.doi.org/10.22159/ijap.2020v12i5.38463. Journal homepage: https://innovareacademics.in/journals/index.php/ijap

\section{INTRODUCTION}

Nowadays, transdermal delivery is the most successful and fruitful drug delivery system and became an inventive target for research in drug delivery. It delivers the drug into the systemic circulation at a predetermined and controlled rate through the skin. It has some advantages such as a non-invasive route, self-administration, bypasses the gastrointestinal tract, reduces the dosage with side effects, increases patient compliance with safety, enhances the bioavailability with therapeutic efficiency. In recent years, various novel concepts are developed to achieve controlled or targeted delivery of drugs with the safest administration. Among them, vesicular carriers such as proniosomes, liposomes, niosomes, ethosomes, etc. are used to attain controlled and targeted drug delivery [1-3].

Proniosomes are nano-sized vesicular structures of dry, free-flowing powder (or) gel with drug encapsulation in the vesicle that produce multilamellar niosomal dispersion after hydration. The Proniosome powder is hydrated into niosomal suspension immediately before administration by brief agitation with a hot aqueous medium which is convenient for oral or other routes; and in case of proniosomal gel, proniosomes are converted into niosomes in situ by absorbing the water from the skin after topical application. This mechanism was shown in fig. 1 [4-6].

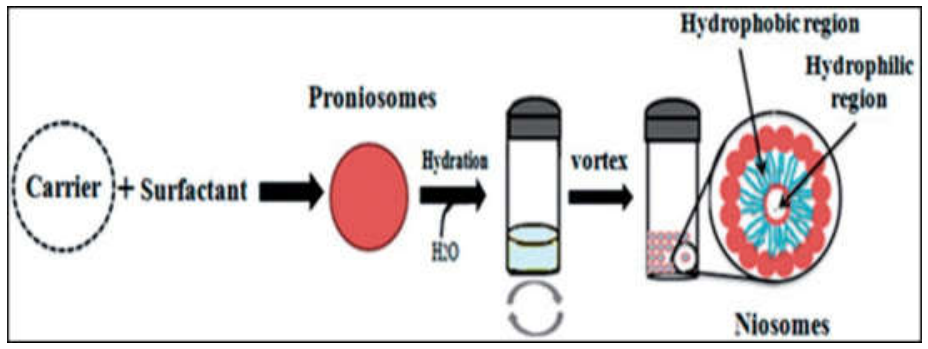

Fig. 1: Conversion of proniosome into noisome [7]

Priniosomal gels are semisolid products formed by the coacervation phase separation method, which involves the admixture of nonionic surfactant, cholesterol in a minimal amount of alcohol with subsequent hydration in aqueous media. They appear as a clear, transparent, or translucent semisolid gel texture, which makes them stable physically during storage. They provide the controlled drug 
release, enhancement of drug penetration with reduced toxic effects; and also prevent the other physical stability problems of niosomes such as aggregation, fusion, leaking, and have additional transport, distribution, storage, dosing and design convenience [8-10].

The proniosomal delivery has attracted the transdermal route for the potential delivery of drugs because both nonionic surfactants and phospholipids themselves act as penetration enhancers. The non-ionic surfactant and cholesterol ratio can alter both the release characteristics and the encapsulation efficiency of the entrapped drugs. It also improves the release and permeation of active agents via skin and also governs the rate of the drug release mechanism. After the application of proniosomes to the skin, they get hydrated to form niosome vesicles, and a high thermodynamic activity gradient develops at the contact, which increases the permeability of the drug. Thereby, the drug penetrates the skin layers and it can be absorbed into systemic circulation via capillaries. The mechanism of permeation was shown in fig. 2 . The Gels became more familiar because of ease of applicability, good percutaneous permeation, controlled drug release characteristics than other semi-solid preparations. Hence, proniosomes are commonly prepared in gel formulation $[6,7,11]$.

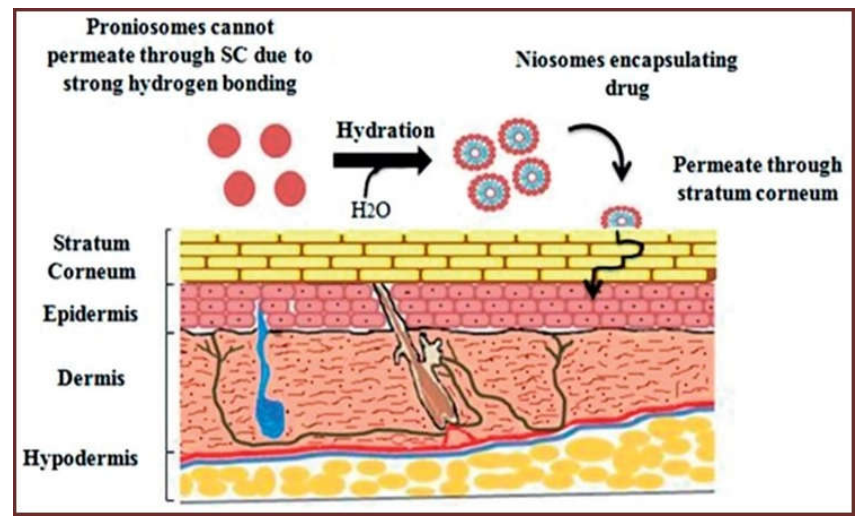

Fig. 2: Mechanism of permeation [7]

EM is an Angiotensin-Converting Enzyme inhibitor commonly employed to treat hypertension and congestive heart failure. It is a suitable drug for anti-hypertensive therapy because of low toxicity and high efficiency. EM possesses ideal characteristics such as a low molecular weight, which is 492.53 (below 600 daltons), smaller dose range $(2.5-20 \mathrm{mg})$, short plasma half-life $(1.3 \mathrm{~h})$, and poor oral bioavailability (50-60 \%) for suitability as a transdermal formulation. Hence, it was selected in the nanoproniosomal gel formulation for the transdermal route [12-14]. The prime goal of the investigation was to formulate the nanoproniosomal gel of EM for the efficient treatment of hypertension through the transdermal route and to provide better bioavailability.

\section{MATERIALS AND METHODS}

\section{Materials}

EM was obtained as a gift sample from Lee Pharma Limited, Hyderabad, India. Cholesterol, Soya Lecithin, Span 20, Span 40 Tween 60, Tween 80 were obtained from Himedia Laboratories Pvt Ltd, Mumbai, India. Brij 30, Brij 72 were obtained from SigmaAldrich, Hyderabad, India. Methylprednisolone acetate (MPA) injection (Depo-Medrol ${ }^{\mathrm{TM}}$ ) manufactured by Pfizer was purchased from a medical shop. All other chemicals and reagents used were of research-grade.

\section{Methods}

\section{Standard curve of pure drug}

It was carried out by preparing the stock solution by dissolving 100 $\mathrm{mg}$ of the drug in $100 \mathrm{ml}$ phosphate buffer $\mathrm{pH} 7.2$ to obtain $1 \mathrm{mg} / \mathrm{ml}$ concentration. Then serial aliquots were prepared to produce different concentrated sample solutions in the range of $2-20 \mu \mathrm{g} / \mathrm{ml}$. The samples were analyzed against the blank by using the Ultra Violet (UV) spectroscopy at an absorption maximum of $206 \mathrm{~nm}$ [15-17].

\section{Drug-Excipient compatibility study}

Fourier Transform-Infrared Spectroscopy (FT-IR Spectroscopy) was done to investigate and predict the physicochemical interaction between formulation components such as lecithin, cholesterol with drug substance. A small amount of sample was mounted on the sample handling stage and scanned in an FTIR spectrophotometer
The IR spectrum of the pure drug was compared with the physical mixtures of drug and excipients, and peak matching was carried out to determine the disappearance or appearance of peaks [18-20].

\section{Preparation of nanoproniosomal gel}

It was prepared by the Coacervation-phase separation method. In this method, the nonionic surfactants were weighed and put in a wide mouth glass vial with a tightly screwed cap. Then an accurate amount of drug, cholesterol, and lecithin was added to the glass vial. After mixing all these ingredients in a glass vial, ethanol was included and mixed up thoroughly. Heat the above solution until the cholesterol lecithin, and drug were completely dissolved in surfactant until the appearance of a clear gel (Usually it takes about 20-25 min for soya lecithin to completely dissolve in surfactant). To this clear solution like gel, then add $0.1 \%$ glycerol solution (it acts as an aqueous phase) and was gently heated until a clear solution (usually it takes about $10 \mathrm{~min}$ ) obtained, later cooled down while mixing it with a glass rod at regular intervals. Finally, that results in the formation of nanoproniosomal gel [21-23]. The schematic representation of this method was shown in fig. 3. The formulation was shown in table 1.

\section{Evaluation of nanoproniosomal gel}

pH

The $\mathrm{pH}$ of the proniosomal gel formulations was performed in triplicate by using the calibrated digital $\mathrm{pH}$ meter [25].

Viscosity

The viscosity of the formulations was measured by using Brookfield Viscometer (DV-E). $10 \mathrm{~g}$ of the gel was taken into a beaker, the spindle of a viscometer was dipped into the gel and then viscosity was determined by rotating the spindle 06 at $100 \mathrm{rpm}[23,25]$

\section{Vesicle size determination (Microscopic evaluation)}

The required quantity of proniosomal gel $(100 \mathrm{mg})$ was hydrated with Phosphate Buffer Saline $(10 \mathrm{ml})$ in a small vial and was manually shaken for $5 \mathrm{~min}$. The formed niosomes were microscopically examined by an optical microscope at $100 \mathrm{X}$ magnification. The average size of vesicles was measured using calibrated ocular and stage micrometers in the microscope $[9,22,26]$ 
Table 1: Formulation table of nanoproniosomal gel of EM

\begin{tabular}{|c|c|c|c|c|c|c|c|c|c|c|c|c|c|}
\hline \multirow{2}{*}{$\begin{array}{l}\text { Ingredients } \\
\text { (mg) }\end{array}$} & \multicolumn{13}{|c|}{ Formulation code } \\
\hline & EMNP1 & EMNP2 & EMNP3 & EMNP4 & EMNP5 & EMNP6 & EMNP7 & EMNP8 & EMNP9 & EMNP10 & EMNP11 & EMNP12 & EMNP13 \\
\hline Drug & 10 & 10 & 10 & 10 & 10 & 10 & 10 & 10 & 10 & 10 & 10 & 10 & 10 \\
\hline Lecithin & 100 & 100 & 100 & 100 & 100 & 100 & 100 & 100 & 100 & 100 & 100 & 100 & 100 \\
\hline Cholesterol & 100 & 100 & 100 & 100 & 100 & 100 & 100 & 100 & 100 & 100 & 100 & 100 & 100 \\
\hline Span 20 & 1000 & -- & -- & -- & -- & -- & 500 & -- & -- & 500 & 500 & -- & -- \\
\hline Span 40 & -- & 1000 & -- & -- & -- & -- & 500 & -- & -- & -- & -- & 500 & 500 \\
\hline Tween 60 & -- & -- & 1000 & -- & -- & -- & -- & 500 & -- & 500 & -- & 500 & -- \\
\hline Tween 80 & -- & -- & -- & 1000 & -- & -- & -- & 500 & -- & -- & 500 & -- & 500 \\
\hline Brij 72 & -- & -- & -- & -- & 1000 & -- & -- & -- & 500 & -- & -- & -- & -- \\
\hline Brij 30 & -- & -- & -- & -- & -- & 1000 & -- & -- & 500 & -- & -- & -- & -- \\
\hline Alcohol (ml) & 0.5 & 0.5 & 0.5 & 0.5 & 0.5 & 0.5 & 0.5 & 0.5 & 0.5 & 0.5 & 0.5 & 0.5 & 0.5 \\
\hline $\begin{array}{l}0.1 \% \\
\text { glycerol } \\
\text { solution(ml) }\end{array}$ & QS & QS & QS & $\mathrm{QS}$ & QS & $\mathrm{QS}$ & QS & $\mathrm{QS}$ & QS & QS & QS & QS & QS \\
\hline
\end{tabular}

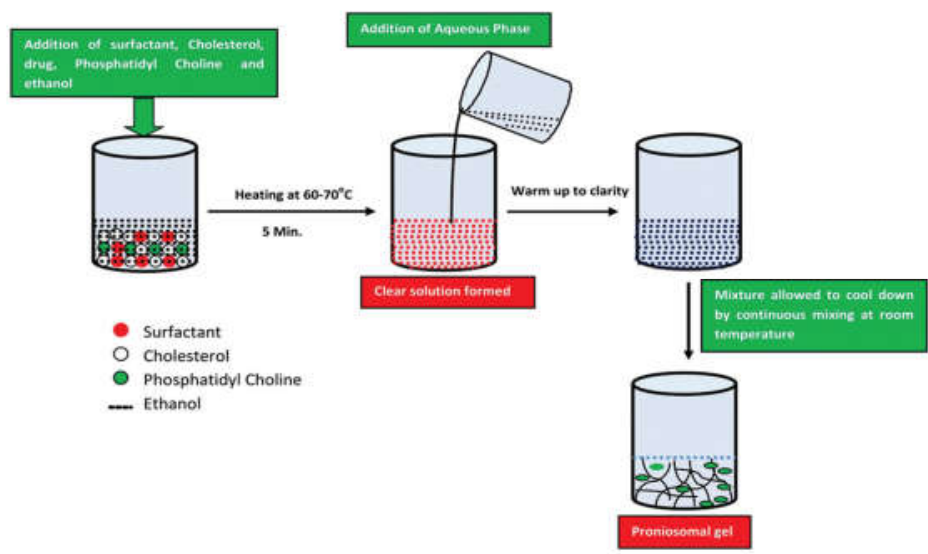

Fig. 3: Coacervation phase separation method [24]

\section{Rate of spontaneity}

Spontaneity can be defined as the number of niosomes produced spontaneously upon hydration of proniosomes for 15-20 min. The specified quantity (10 or $20 \mathrm{mg}$ ) of proniosomal gel was transferred into a clean stoppered glass container and was spread along the walls of a glass container uniformly with the help of a glass rod. Then, $2 \mathrm{ml}$ of saline solution $(0.9 \% \mathrm{NaCl})$ was added cautiously to the walls of a glass container and kept aside in an undisturbed position for $20 \mathrm{~min}$. After that, a drop of this solution was placed on the Neubauer's chamber to count the number of vesicles (niosomes) formed from proniosomes [9, 21, 27].

\section{Entrapment efficiency}

To assess the stacking limit of the proniosomal frameworks for EM, the proniosomal gel $(100 \mathrm{mg})$ was scattered in refined water and warmed a little for the development of niosomes. This dispersion was centrifuged at $18000 \mathrm{rpm}$ for $40 \mathrm{~min}$ at $5{ }^{\circ} \mathrm{C}$ (Remi CPR-24 axis). The supernatant portion was utilized for the assurance of free medication at $206 \mathrm{~nm}$ by spectrophotometrically $[9,27]$.

The rate of entrapment efficiency was determined from

$$
\% \text { Encapsulation Efficiency }=1-\frac{\text { (Unencapsulated drug) }}{\text { (Total drug) }} \times 100
$$

\section{Ethical clearance approval}

Ethical clearance was obtained from the Institutional Animal Ethical Committee (IAEC) for the handling of experimental animals for evaluation tests such as Ex Vivo Skin permeation studies, Skin irritation studies, and In vivo antihypertensive studies. The protocol of the animal study was approved by IAEC, Protocol Number: SVCP/IAEC/II-012/2019-20 dt 18.11.19. The experiment was carried out as per the guidelines of the Committee for the purpose of control and supervision of experiments on animals (CPCSEA)

\section{Ex vivo skin permeation studies}

Albino rats weighing 150-200 g were selected for permeation study. The rats were obtained from Sree Venkateshwara Enterprises, Bengaluru. The animals were kept under standard laboratory conditions, with a temperature of $25 \pm 1{ }^{\circ} \mathrm{C}$ and relative humidity of $55 \pm 5 \%$. They are placed properly in animal cages with free access to diet and water. The Rat was sacrificed using anesthetic ether, and hair of the test animal was trimmed short $(<2 \mathrm{~mm})$ with scissors. Approximately 4.5 to $5.0 \mathrm{~cm}^{2}$ of the full thickness of the skin was excised from the shaved abdomen site After the removal of the subcutaneous fat, the skin sample was washed in distilled water and an isotonic phosphate buffer. The separated skin was cut into the required size and wrapped in aluminum foil and stored in a deep freezer at- $20^{\circ} \mathrm{C}$ until further use (used within two weeks of preparation).

These studies were performed by using a modified Franz-diffusion cell. It contains a receptor compartment with a volume of approximately $60 \mathrm{ml}$ and a surface area approximately $3.14 \mathrm{~cm}^{2}$ for permeation. The excised albino rat skin was incorporated between the donor and receptor compartments. A precise quantity of proniosomal gel was placed above the skin towards the donor compartment and the receptor compartment was filled with phosphate saline buffer $\mathrm{pH}$ 7.2. The heat was provided to maintain the required temperature at $37 \pm 0.5{ }^{\circ} \mathrm{C}$ by using a thermostatic hot plate fixed to a magnetic stirrer. The receptor diffusion medium was stirred by a Teflon-coated magnetic bead placed inside a receptor compartment

At appropriate time intervals, samples were withdrawn and were replaced by equal volumes of fresh receptor fluid on each 
withdrawal, and samples were analyzed spectrophotometrically at $206 \mathrm{~nm}[9,18,21,22,28]$.

\section{Release kinetics}

To determine the mode and mechanism of drug release, the data obtained from the ex vivo permeation profiles were fitted in various kinetic models such as zero-order kinetic model (cumulative $\%$ drug release versus time), first-order kinetic model (log cumulative of \% drug remaining versus time), Higuchi's model (cumulative \% drug release versus square root of time) and Korsmeyer-peppa's model (log cumulative \% drug release versus log time) $[18,19,29]$.

\section{Permeation kinetic studies}

\section{Permeability coefficient (P)}

It is the capability of drug permeation through the semi-permeable membrane in $\mathrm{mg} / \mathrm{cm}^{2} / \mathrm{h}$. It was determined from the slope of the plot of the percentage of drug transported versus time, was calculated by dividing $\mathrm{J}_{\mathrm{ss}}$ by the initial drug concentration of the donor cell $\left(\mathrm{C}_{0}\right)$.

$$
\mathrm{P}=\frac{\mathrm{Jss}}{\mathrm{Co}}
$$

\section{Flux (Jss)}

It is defined as the amount of substance passing through a unit cross-sectional barrier in unit time. It was determined from the slope of the plot of the percentage of drug transported versus time, and it was calculated by, dividing the slope of the linear portion of the plot by the surface area of the diffusion cell.

$$
\text { Jss }=\frac{\text { Slope of the plot }}{\text { Surface area of the diffusion cell }}
$$

\section{Enhancement ratio $\left(\mathrm{E}_{\mathrm{r}}\right)$}

It is an important parameter used to determine the effect of permeation enhancer on diffusion and permeability characteristics of the drug substance. It was calculated by, dividing the $\mathrm{J}_{\mathrm{ss}}$ of the particular formulation by the $\mathrm{J}_{\mathrm{ss}}$ of the control formulation $[30,31]$.

$$
\mathrm{Er}=\frac{\text { Jss of the formulation }}{\text { Jss of the control }}
$$

\section{Semi electron microscopy (SEM)}

It was carried out to evaluate the morphological features of the niosomes, which were formed upon hydration of proniosomal formulations. In this study, a precise quantity of proniosomal gel was diluted with phosphate buffer $\mathrm{pH} 7.2$ in a glass test tube and the formed vesicles were dispersed on an adhesive carbon tape placed on an aluminum stub. The samples were coated with gold using a vacuum evaporator $\left(3 \times 10^{-1} \mathrm{~atm}\right)$ and were examined at $25 \mathrm{kV}$ accelerating voltage under SEM fitted with a digital camera $[18,22,26]$.

\section{Zeta potential}

It is a measure of net charge on the surface of niosomes. If zeta potential increases, then the repulsive forces between the vesicles also increase, which prevents the agglomeration of vesicles and produces evenly distributed and stable niosomal suspension. It was determined by using a HORIBA SZ-100 Zeta meter [18, 21, 32].

\section{Skin irritation studies}

The skin irritation test was done on healthy albino rats weighing between 160 to $180 \mathrm{~g}$. It was carried out as per the guidelines of
Organisation for Economic Co-operation and Development (OECD). The rats were obtained from Sree Venkateshwara Enterprises, Bengaluru. The animals were kept under standard laboratory conditions, with a temperature of $25 \pm 1{ }^{\circ} \mathrm{C}$ and relative humidity of $55 \pm 5 \%$. They are placed properly in animal cages with free access to diet and water. On the previous day of the experiment, the hair on the backside of the animal was removed. In this study, $0.5 \mathrm{~g}$ of proniosomal gel was applied to 3 rats on an area of skin approximately 1"x1" (2.54 x $2.54 \mathrm{~cm})$ square, and animals were placed in their cages. After the exposure to $24 \mathrm{~h}$, the proniosomal gel was removed and the test sites were washed with tap water to remove any sign of test article residue. This study was performed on one rat initially (Initial skin irritation test) and later conducted on two rats (confirmatory skin irritation test). The Erythema and Edema were to be observed. Finally, the test sites were to be graded as per the visual scoring scale [22, 28, 33-35].

The erythema scale is as follows:
$0 . \quad$ none
1. slight
2. well defined
3. moderate
4. scar formation

The edema scale is as follows:

0 . none

1. slight

2. well defined

3. moderate

4. severe

\section{Stability studies}

The stability of a product is defined as the potential of a specific dosage form in a suitable container to remain with the physical, chemical, microbiological, therapeutic, and toxicological characteristics at the time of manufacture. The stability study was conducted as per the International Conference on Harmonisation (ICH) guidelines and it was done to detect the drug degradation from proniosomal gel during the storage period. In this study, the prepared formulations were stored at Refrigeration Temperature $\left(4-8{ }^{\circ} \mathrm{C}\right)$, Room Temperature $\left(25 \pm 2{ }^{\circ} \mathrm{C}\right)$, Oven $\left(45 \pm 2{ }^{\circ} \mathrm{C}\right)$ for $45 \mathrm{~d}$. The proniosomal formulation was stored in aluminum foil sealed glass vials for all over the study. At different time intervals, samples were collected and analyzed for drug content, physical appearance, homogeneity, vesicle size, $\mathrm{pH}$, and a viscosity $[9,22,36]$.

\section{In vivo antihypertensive studies}

Healthy male Albino Wistar rats were (weighing approximately $250 \pm 25 \mathrm{~g}$ ) selected for this study, and all the animals were healthy during the period of the experiment. The animals were kept under standard laboratory conditions, with a temperature of $25 \pm 1{ }^{\circ} \mathrm{C}$ and relative humidity of $55 \pm 5 \%$. The animals were placed properly in polypropylene cages, 6 per cage, with free access to a standard laboratory diet (Lipton feed) and water ad libitum. The dose for the rats was determined based on the body weight and surface area ratio.

Thirty rats were taken and separated into five categories (Group A to E), each carrying six rats. Group A was considered as control and hypertension was induced in other rats (Group B to E) by injecting MPA $(20 \mathrm{mg} / \mathrm{kg} / \mathrm{w})$ subcutaneously for two weeks. Treatments

\begin{tabular}{|c|c|c|c|c|}
\hline S. No. & Group & Treatments & No. of rats in group & Measurement of BP at different time intervals (h) \\
\hline 1 & A & Control & 6 & $0,1,2,3,4,6,8,10,12,24$ \\
\hline 2 & $\mathrm{~B}$ & Only MPA & 6 & $0,1,2,3,4,6,8,10,12,24$ \\
\hline 3 & $\mathrm{C}$ & MPA+placebo EMNP7 & 6 & $0,1,2,3,4,6,8,10,12,24$ \\
\hline 4 & $\mathrm{D}$ & MPA+EMNP7 & 6 & $0,1,2,3,4,6,8,10,12,24$ \\
\hline 5 & $\mathrm{E}$ & MPA+Marketed tablet & 6 & $0,1,2,3,4,6,8,10,12,24$ \\
\hline
\end{tabular}
given to each group were indicated in table 2 .

Table 2: Treatment given to the different groups of animals 
Before the application of the gel, the rat skin was first visually evaluated to check normal skin condition. Then, the dorsal part of the hair was carefully shaved or clipped without damaging the stratum corneum, and the skin was gently wiped with warm water followed by an alcohol swab and patted dry. Then, selected formulation EMNP7 was applied evenly to the surface of the previously shaven area of rat skin. To keep the gel secured at the site of application, the microporous adhesive tape was rolled over the gel. Then rats were placed in the animal holder and had free access to water and food. Then BP was determined from the rat tail at predetermined time intervals up to $24 \mathrm{~h}$ using the rat BP instrument (Biopac system, USA) and based on a non-invasive BP measuring method. The device consists of a scanner, a tail-cuff, an animal holder attached to the main instrument having a digital BP display panel [37-39].

Statistical analysis: The data was statistically analyzed by using a one-way analysis of variance. A Dunette multiple comparison test and paired t-test using GRAPHPAD INSTAT 3 software (Graph-Pad Software Inc.) were used to test the different formulations and the level of significance was taken as $\mathrm{p}<0.05$.

\section{RESULTS AND DISCUSSION \\ Preparation of standard curve of EM}

The standard curve of the pure drug was constructed by using phosphate buffer $\mathrm{pH}$ 7.2. The slope of the given data was found to be 0.0468 and regression was found to be $\mathrm{R}^{2}=0.9998$. The present analytical method suggests that the drug obeyed the Beer's lambert's linearity principles within limits of 2 to $20(\mu \mathrm{g} / \mathrm{ml})$ and was suitable in the estimation of EM in phosphate buffer 7.2 at 206 $\mathrm{nm}$ by UV spectrophotometer. The standard curve table and graph were shown in table 3 and fig. 4, respectively.

\section{Drug-excipient compatibility study}

FT-IR Spectra of all excipients do not show any significant changes in the functional group and fingerprint region, indicating no interaction between pure drug and excipients. These results depicted that the $\mathrm{EM}$ is compatible with selected excipients in nanoproniosomal formulation. The graphs of FTIR spectra were shown in fig. 5 and 6 and their interpretation was shown in table 4 , respectively.

Table 3: Construction of standard curve in phosphate buffer 7.2

\begin{tabular}{ll}
\hline Concentration $(\boldsymbol{\mu g} / \mathbf{m l})$ & Absorbance at $\mathbf{2 0 6} \mathbf{~ n m}$ \\
\hline 0 & 0 \\
2 & 0.103 \\
4 & 0.200 \\
6 & 0.291 \\
8 & 0.380 \\
10 & 0.474 \\
12 & 0.560 \\
14 & 0.657 \\
16 & 0.751 \\
18 & 0.849 \\
20 & 0.950 \\
\hline
\end{tabular}

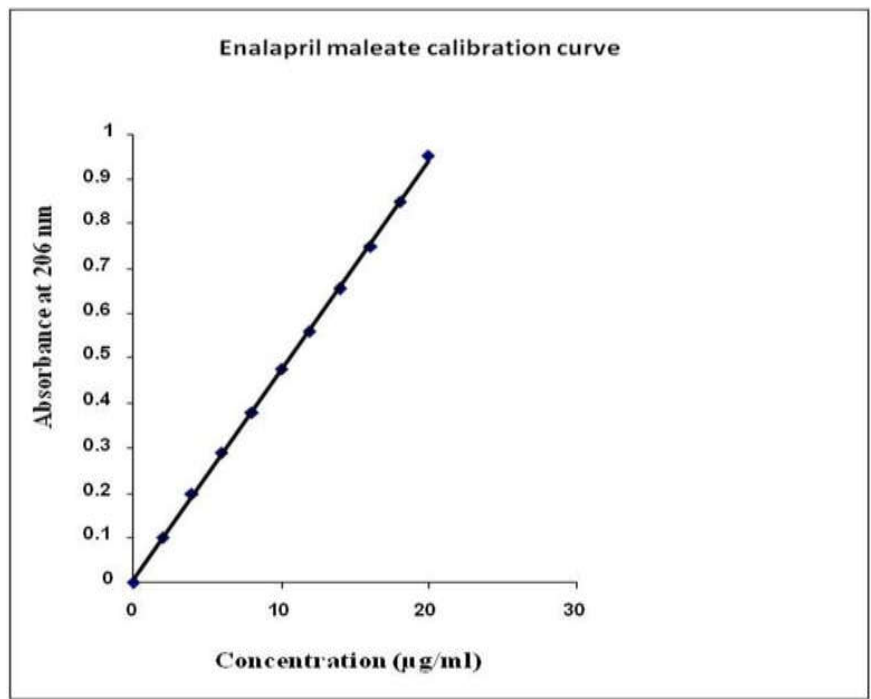

Fig. 4: Construction of standard curve in phosphate buffer 7.2

Table 4: Interpretation of FT-IR of drug

\begin{tabular}{lll}
\hline S. No. & Wave in cm & Functional group \\
\hline 1 & 3025.75 & C-H Aromatic stretching \\
2 & 1597.24 & Benzene ring \\
3 & $1597.24,1727.80$ & Carbonyl group \\
4 & 1361.56 & - OH group \\
5 & $1361.56,1300.42$ & Tertiary aromatic nitrogen \\
6 & $1267.85,1361.56$ & Secondary aliphatic amine \\
\hline
\end{tabular}




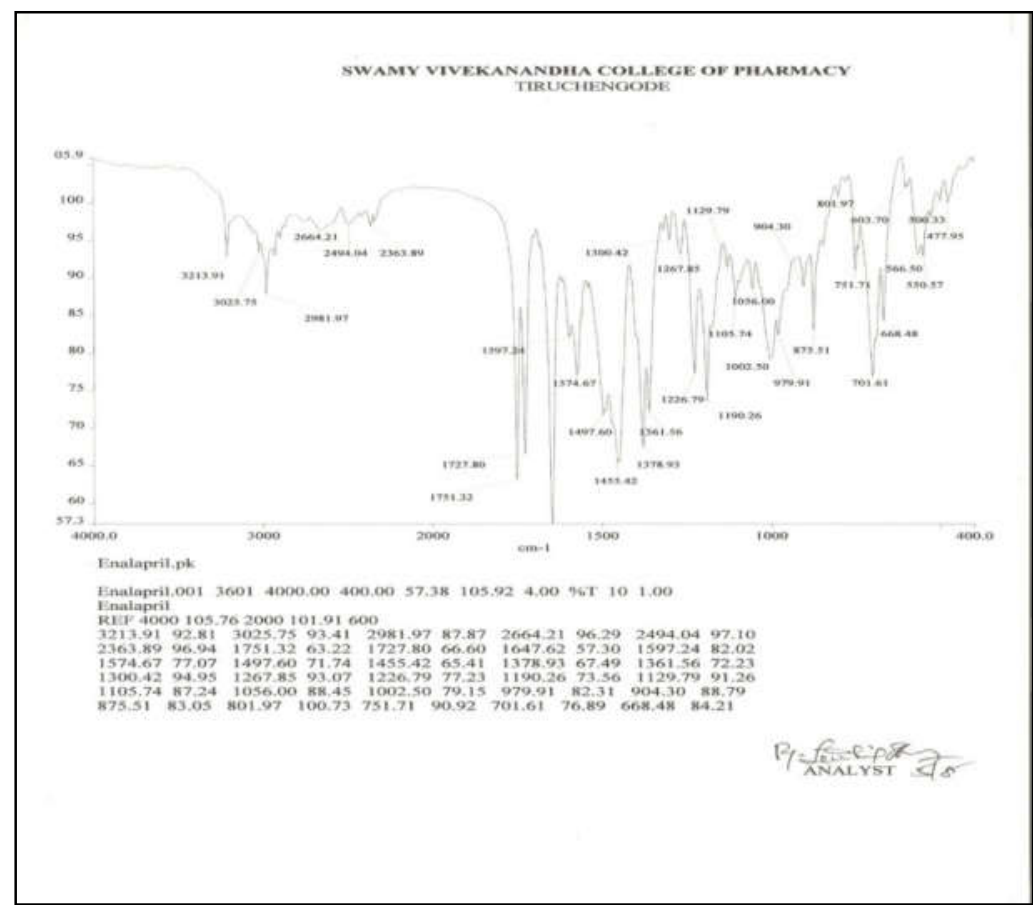

Fig. 5: FT-IR spectra of pure EM

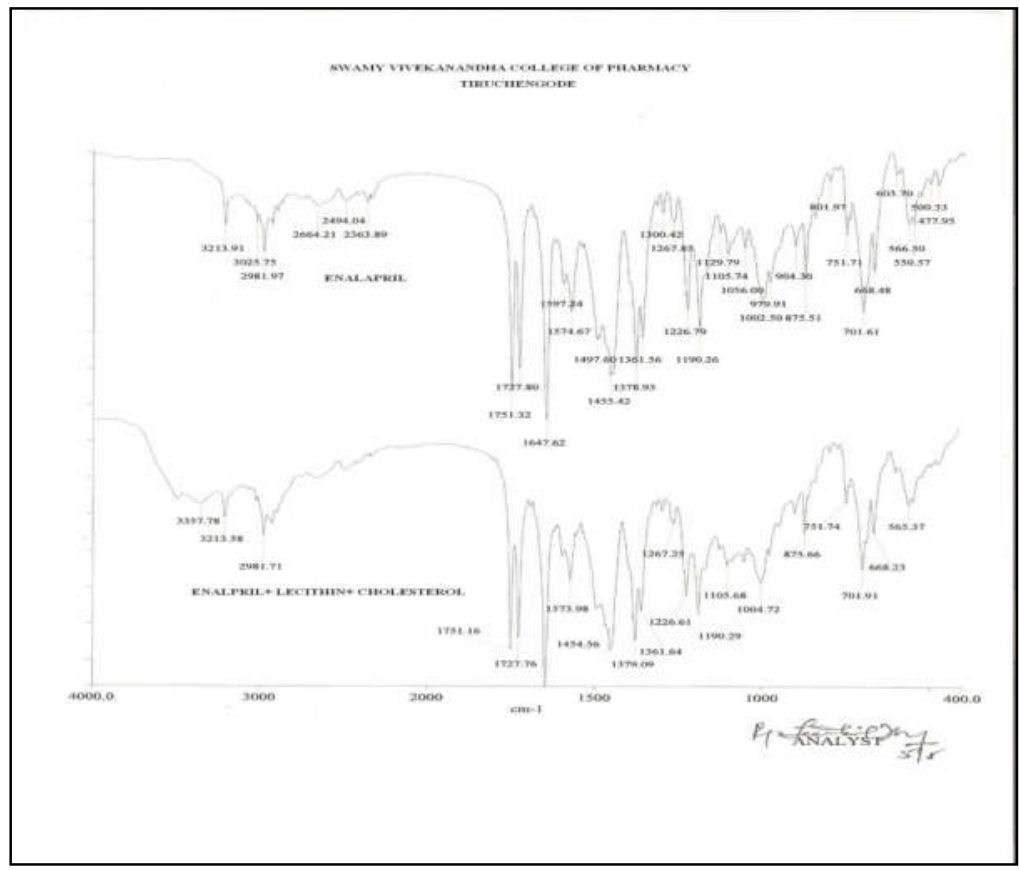

Fig. 6: FT-IR spectra of the physical mixture of enalapril, lecithin, and cholesterol

\section{Physicochemical characterization of proniosomal gel}

The EM nanoproniosomal gel was characterized for physicochemical properties and the results were given in table 5 .

The $\mathrm{pH}$ of all the formulations was around 6.7 and 7.3, which means that they are safer to administer through the transdermal route.

The vesicle size of the formulations was found to be in the range of 5.2-21.6 $\mu \mathrm{m}$ that shows the spans (Span 20, Span 40) form smaller size vesicles and greater encapsulation efficiency than tweens and brij surfactants. The results were in good agreement with Khanderao R. Jadhav et al. (2016) who described that spans form smaller size vesicles when compared with other nonionic surfactants [24].

The rate of the spontaneity of the formulations was found to be in the range of $8-16$, which indicates the number of niosomes formed from the proniosomes after hydration. 
The Entrapment Efficiency of the formulations was found to be in the range of $53.36 \%-85.23 \%$ and the viscosity of the formulations was obtained in the range of 8751-12340 cps. The results were accepted with Khanderao R. Jadhav et al. (2016), who described that surfactants having hydrophilic-lipophilic balance in the range of 4 to 8 produce stable proniosomes with good entrapment efficiency [24].

All the prepared formulations showed good physicochemical characteristics and are within limits.

Table 5: Physicochemical characterization

\begin{tabular}{|c|c|c|c|c|c|}
\hline Formulation code & $\mathbf{p H}^{*}$ & Vesicle size $^{*}(\mu \mathrm{m})$ & Rate of spontaneity* & Entrapment efficiency \%* & Viscosity (cps)* \\
\hline EMNP1 & $6.7 \pm 0.45$ & $8.3 \pm 0.80$ & $10 \pm 3.07$ & $80.61 \pm 0.28$ & $10496 \pm 1.72$ \\
\hline EMNP2 & $6.8 \pm 0.03$ & $7.5 \pm 0.42$ & $13 \pm 0.73$ & $82.46 \pm 0.47$ & $11307 \pm 1.59$ \\
\hline EMNP3 & $7.0 \pm 0.63$ & $20.2 \pm 1.34$ & $9 \pm 2.58$ & $53.36 \pm 0.41$ & $11824 \pm 3.96$ \\
\hline EMNP4 & $7.2 \pm 0.57$ & $21.6 \pm 1.05$ & $8 \pm 1.62$ & $55.52 \pm 0.98$ & $12067 \pm 2.58$ \\
\hline EMNP5 & $6.9 \pm 0.48$ & $12.7 \pm 2.83$ & $14 \pm 1.04$ & $74.94 \pm 0.57$ & $8751 \pm 1.97$ \\
\hline EMNP6 & $7.1 \pm 0.52$ & $16.4 \pm 1.72$ & $12 \pm 2.95$ & $73.65 \pm 0.51$ & $9374 \pm 3.86$ \\
\hline EMNP7 & $6.9 \pm 0.74$ & $5.2 \pm 0.64$ & $16 \pm 0.21$ & $85.23 \pm 0.78$ & $10786 \pm 2.05$ \\
\hline EMNP8 & $7.2 \pm 0.34$ & $17.7 \pm 0.36$ & $10 \pm 3.46$ & $62.81 \pm 0.73$ & $9793 \pm 2.82$ \\
\hline EMNP9 & $6.8 \pm 0.61$ & $14.8 \pm 3.61$ & $11 \pm 2.84$ & $71.27 \pm 0.75$ & $10583 \pm 2.62$ \\
\hline EMNP10 & $7.1 \pm 0.06$ & $18.5 \pm 2.95$ & $15 \pm 1.76$ & $66.19 \pm 0.82$ & $10220 \pm 1.63$ \\
\hline EMNP11 & $7.2 \pm 0.32$ & $11.2 \pm 2.24$ & $12 \pm 2.08$ & $75.83 \pm 0.46$ & $10748 \pm 2.95$ \\
\hline EMNP12 & $6.8 \pm 0.05$ & $15.5 \pm 3.02$ & $10 \pm 3.65$ & $77.68 \pm 0.13$ & $11526 \pm 3.74$ \\
\hline EMNP13 & $7.3 \pm 0.08$ & $12.4 \pm 1.87$ & $13 \pm 1.94$ & $76.29 \pm 0.35$ & $12340 \pm 1.85$ \\
\hline
\end{tabular}

${ }^{*}$ Average of three values, ${ }^{ \pm}$Standard deviation

\section{Microscopic evaluation}

The microscopic evaluations of the formulation showed that the formulations are in good physical shape and size. The microscopic images were shown in fig. 7 to 9 .

\section{Ex vivo skin permeation studies}

The skin permeation data of the formulations were shown in table 6 and fig. 10. The percentage drug permeation of EMNP7 was found to be the highest among all, around $89.72 \%$, than other formulations. The decrease in vesicle size due to nanoproniosomal technology may be the reason for the increase in drug diffusion rate and extent. The results were compared with Ankur Gupta et al. (2007) who studied the Proniosomal transdermal system of an antihypertensive drug, Captopril showed less \% of drug permeation than our formulation [9] and also with Venkata Ramesh Yasam et al. (2014) who studied the Proniosomal transdermal delivery of an antihypertensive drug, Nifedipine showed less $\%$ of drug permeation than our formulation [18].

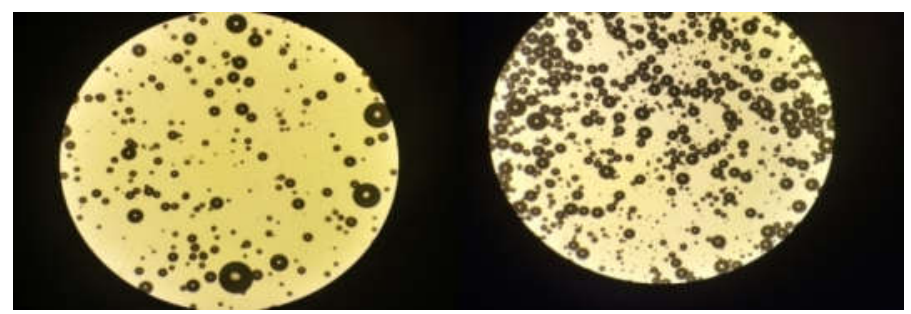

Fig. 7: Microscopic image of EMNP7 (Before and after hydration) formed from spans

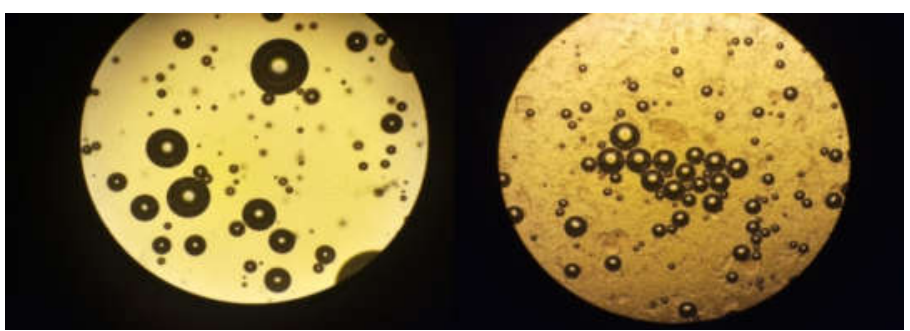

Fig. 8: Microscopic image of EMNP3 (Before and after hydration) formed from tweens

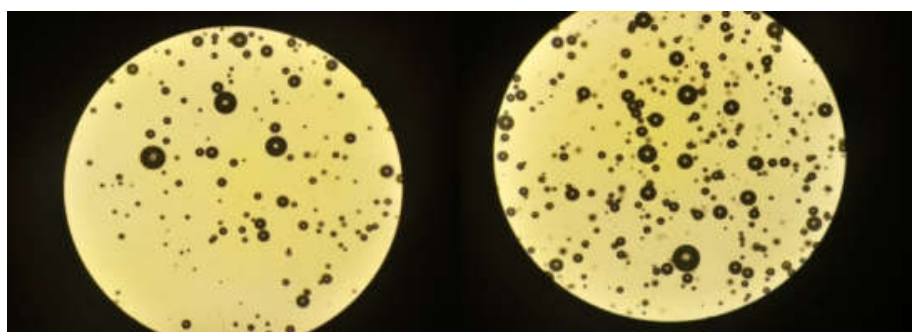

Fig. 9: Microscopic image of EMNP5 (Before and after hydration) formed from brijs 
Table 6: Ex vivo skin permeation studies*

\begin{tabular}{|c|c|c|c|c|c|c|c|c|c|c|c|c|c|}
\hline $\begin{array}{l}\text { Time } \\
\text { (h) }\end{array}$ & $\begin{array}{l}\text { EMNP } \\
1\end{array}$ & $\begin{array}{l}\text { EMNP } \\
2\end{array}$ & $\begin{array}{l}\text { EMNP } \\
3\end{array}$ & EMNP4 & EMNP5 & EMNP6 & EMNP7 & EMNP8 & EMNP9 & $\begin{array}{l}\text { EMNP1 } \\
0\end{array}$ & $\begin{array}{l}\text { EMNP1 } \\
1\end{array}$ & $\begin{array}{l}\text { EMNP1 } \\
2\end{array}$ & $\begin{array}{l}\text { EMNP1 } \\
3\end{array}$ \\
\hline 0 & 0 & 0 & 0 & 0 & 0 & 0 & 0 & 0 & 0 & 0 & 0 & 0 & 0 \\
\hline 1 & $\begin{array}{l}7.53 \pm 0 . \\
12\end{array}$ & $\begin{array}{l}8.34 \pm 0 . \\
34\end{array}$ & $\begin{array}{l}6.28 \pm 0 \\
60\end{array}$ & $\begin{array}{l}5.73 \pm 0 \\
38\end{array}$ & $\begin{array}{l}8.67 \pm 0 \\
62\end{array}$ & $\begin{array}{l}8.49 \pm 0 \\
33\end{array}$ & $\begin{array}{l}9.82 \pm 0 \\
55\end{array}$ & $\begin{array}{l}6.45 \pm 0 \\
23\end{array}$ & $\begin{array}{l}8.33 \pm 0 \\
11\end{array}$ & $\begin{array}{l}6.17 \pm 0 \\
27\end{array}$ & $\begin{array}{l}5.28 \pm 0 \\
51\end{array}$ & $\begin{array}{l}7.92 \pm 0 \\
09\end{array}$ & $\begin{array}{l}6.71 \pm 0 \\
41\end{array}$ \\
\hline 2 & $\begin{array}{l}15.15 \pm \\
0.35\end{array}$ & $\begin{array}{l}14.31 \pm \\
0.42\end{array}$ & $\begin{array}{l}11.51 \pm \\
0.27\end{array}$ & $\begin{array}{l}12.44 \pm \\
0.49\end{array}$ & $\begin{array}{l}13.78 \pm \\
0.88\end{array}$ & $\begin{array}{l}14.20 \pm \\
0.74\end{array}$ & $\begin{array}{l}16.05 \pm \\
0.06\end{array}$ & $\begin{array}{l}10.12 \pm \\
0.35\end{array}$ & $\begin{array}{l}14.11 \pm \\
0.24\end{array}$ & $\begin{array}{l}11.20 \pm \\
0.14\end{array}$ & $\begin{array}{l}9.31 \pm 0 . \\
28\end{array}$ & $\begin{array}{l}11.43 \pm \\
0.35\end{array}$ & $\begin{array}{l}12.07 \pm \\
0.52\end{array}$ \\
\hline 4 & $\begin{array}{l}23.36 \pm \\
0.41\end{array}$ & $\begin{array}{l}22.25 \pm \\
0.59\end{array}$ & $\begin{array}{l}16.73 \pm \\
0.49\end{array}$ & $\begin{array}{l}17.86 \pm \\
0.63\end{array}$ & $\begin{array}{l}19.03 \pm \\
0.40\end{array}$ & $\begin{array}{l}18.66 \pm \\
0.07\end{array}$ & $\begin{array}{l}24.10 \pm \\
0.17\end{array}$ & $\begin{array}{l}15.45 \pm \\
0.87\end{array}$ & $\begin{array}{l}22.03 \pm \\
0.75\end{array}$ & $\begin{array}{l}15.09 \pm \\
0.36\end{array}$ & $\begin{array}{l}14.07 \pm \\
0.49\end{array}$ & $\begin{array}{l}17.49 \pm \\
0.14\end{array}$ & $\begin{array}{l}16.67 \pm \\
0.58\end{array}$ \\
\hline 6 & $\begin{array}{l}29.27 \pm \\
0.32\end{array}$ & $\begin{array}{l}28.64 \pm \\
0.51\end{array}$ & $\begin{array}{l}21.80 \pm \\
0.57\end{array}$ & $\begin{array}{l}20.02 \pm \\
0.33\end{array}$ & $\begin{array}{l}24.15 \pm \\
0.06\end{array}$ & $\begin{array}{l}23.04 \pm \\
0.80\end{array}$ & $\begin{array}{l}30.19 \pm \\
0.24\end{array}$ & $\begin{array}{l}22.76 \pm \\
0.66\end{array}$ & $\begin{array}{l}28.77 \pm \\
0.50\end{array}$ & $\begin{array}{l}21.83 \pm \\
0.70\end{array}$ & $\begin{array}{l}18.40 \pm \\
0.75\end{array}$ & $\begin{array}{l}20.11 \pm \\
0.67\end{array}$ & $\begin{array}{l}19.19 \pm \\
0.39\end{array}$ \\
\hline 8 & $\begin{array}{l}35.61 \pm \\
0.04\end{array}$ & $\begin{array}{l}35.72 \pm \\
0.16\end{array}$ & $\begin{array}{l}27.65 \pm \\
0.43\end{array}$ & $\begin{array}{l}25.74 \pm \\
0.05\end{array}$ & $\begin{array}{l}30.69 \pm \\
0.15\end{array}$ & $\begin{array}{l}32.12 \pm \\
0.56\end{array}$ & $\begin{array}{l}38.26 \pm \\
0.35\end{array}$ & $\begin{array}{l}24.99 \pm \\
0.04\end{array}$ & $\begin{array}{l}34.95 \pm \\
0.46\end{array}$ & $\begin{array}{l}26.30 \pm \\
0.55\end{array}$ & $\begin{array}{l}25.99 \pm \\
0.11\end{array}$ & $\begin{array}{l}25.89 \pm \\
0.38\end{array}$ & $\begin{array}{l}24.32 \pm \\
0.70\end{array}$ \\
\hline 10 & $\begin{array}{l}38.57 \pm \\
0.53\end{array}$ & $\begin{array}{l}41.91 \pm \\
0.09\end{array}$ & $\begin{array}{l}34.33 \pm \\
0.50\end{array}$ & $\begin{array}{l}30.93 \pm \\
0.80\end{array}$ & $\begin{array}{l}39.46 \pm \\
0.27\end{array}$ & $\begin{array}{l}36.09 \pm \\
0.44\end{array}$ & $\begin{array}{l}45.37 \pm \\
0.61\end{array}$ & $\begin{array}{l}29.20 \pm \\
0.17\end{array}$ & $\begin{array}{l}40.53 \pm \\
0.71\end{array}$ & $\begin{array}{l}30.55 \pm \\
0.49\end{array}$ & $\begin{array}{l}28.56 \pm \\
0.67\end{array}$ & $\begin{array}{l}31.03 \pm \\
0.91\end{array}$ & $\begin{array}{l}29.94 \pm \\
0.62\end{array}$ \\
\hline 12 & $\begin{array}{l}45.73 \pm \\
0.38\end{array}$ & $\begin{array}{l}49.70 \pm \\
0.71\end{array}$ & $\begin{array}{l}39.61 \pm \\
0.67\end{array}$ & $\begin{array}{l}36.89 \pm \\
0.73\end{array}$ & $\begin{array}{l}46.37 \pm \\
0.83\end{array}$ & $\begin{array}{l}41.27 \pm \\
0.36\end{array}$ & $\begin{array}{l}53.42 \pm \\
0.45\end{array}$ & $\begin{array}{l}35.08 \pm \\
0.40\end{array}$ & $\begin{array}{l}47.81 \pm \\
0.06\end{array}$ & $\begin{array}{l}36.79 \pm \\
0.18\end{array}$ & $\begin{array}{l}36.48 \pm \\
0.08\end{array}$ & $\begin{array}{l}37.44 \pm \\
0.82\end{array}$ & $\begin{array}{l}35.88 \pm \\
0.88\end{array}$ \\
\hline 14 & $\begin{array}{l}57.81 \pm \\
0.30\end{array}$ & $\begin{array}{l}57.16 \pm \\
0.64\end{array}$ & $\begin{array}{l}45.99 \pm \\
0.75\end{array}$ & $\begin{array}{l}41.22 \pm \\
0.55\end{array}$ & $\begin{array}{l}51.29 \pm \\
0.66\end{array}$ & $\begin{array}{l}48.35 \pm \\
0.31\end{array}$ & $\begin{array}{l}62.57 \pm \\
0.22\end{array}$ & $\begin{array}{l}41.44 \pm \\
0.33\end{array}$ & $\begin{array}{l}55.58 \pm \\
0.33\end{array}$ & $\begin{array}{l}43.54 \pm \\
0.85\end{array}$ & $\begin{array}{l}40.19 \pm \\
0.16\end{array}$ & $\begin{array}{l}42.62 \pm \\
0.29\end{array}$ & $\begin{array}{l}40.63 \pm \\
0.40\end{array}$ \\
\hline 16 & $\begin{array}{l}64.72 \pm \\
0.46\end{array}$ & $\begin{array}{l}63.84 \pm \\
0.83\end{array}$ & $\begin{array}{l}51.08 \pm \\
0.61\end{array}$ & $\begin{array}{l}47.19 \pm \\
0.19\end{array}$ & $\begin{array}{l}58.38 \pm \\
0.57\end{array}$ & $\begin{array}{l}55.29 \pm \\
0.02\end{array}$ & $\begin{array}{l}69.61 \pm \\
0.05\end{array}$ & $\begin{array}{l}47.51 \pm \\
0.31\end{array}$ & $\begin{array}{l}62.70 \pm \\
0.63\end{array}$ & $\begin{array}{l}47.23 \pm \\
0.36\end{array}$ & $\begin{array}{l}47.6 \pm 0 \\
44\end{array}$ & $\begin{array}{l}48.37 \pm \\
0.13\end{array}$ & $\begin{array}{l}44.22 \pm \\
0.36\end{array}$ \\
\hline 18 & $\begin{array}{l}68.19 \pm \\
0.56\end{array}$ & $\begin{array}{l}72.77 \pm \\
0.76\end{array}$ & $\begin{array}{l}59.63 \pm \\
0.10\end{array}$ & $\begin{array}{l}53.11 \pm \\
0.21\end{array}$ & $\begin{array}{l}65.09 \pm \\
0.03\end{array}$ & $\begin{array}{l}63.25 \pm \\
0.14\end{array}$ & $\begin{array}{l}77.79 \pm \\
0.44\end{array}$ & $\begin{array}{l}51.03 \pm \\
0.65\end{array}$ & $\begin{array}{l}70.91 \pm \\
0.16\end{array}$ & $\begin{array}{l}54.86 \pm \\
0.10\end{array}$ & $\begin{array}{l}52.78 \pm \\
0.60\end{array}$ & $\begin{array}{l}55.9 \pm 0 . \\
74\end{array}$ & $\begin{array}{l}48.91 \pm \\
0.06\end{array}$ \\
\hline 20 & $\begin{array}{l}75.34 \pm \\
0.47\end{array}$ & $\begin{array}{l}80.88 \pm \\
0.19\end{array}$ & $\begin{array}{l}66.55 \pm \\
0.24\end{array}$ & $\begin{array}{l}64.46 \pm \\
0.37\end{array}$ & $\begin{array}{l}73.85 \pm \\
0.13\end{array}$ & $\begin{array}{l}70.84 \pm \\
0.86\end{array}$ & $\begin{array}{l}83.51 \pm \\
0.16\end{array}$ & $\begin{array}{l}55.66 \pm \\
0.49\end{array}$ & $\begin{array}{l}78.80 \pm \\
0.24\end{array}$ & $\begin{array}{l}60.22 \pm \\
0.84\end{array}$ & $\begin{array}{l}58.72 \pm \\
0.13\end{array}$ & $\begin{array}{l}64.84 \pm \\
0.63\end{array}$ & $\begin{array}{l}52.70 \pm \\
0.12\end{array}$ \\
\hline 22 & $\begin{array}{l}78.31 \pm \\
0.28\end{array}$ & $\begin{array}{l}83.23 \pm \\
0.39\end{array}$ & $\begin{array}{l}71.96 \pm \\
0.09\end{array}$ & $\begin{array}{l}67.72 \pm \\
0.53\end{array}$ & $\begin{array}{l}76.18 \pm \\
0.59\end{array}$ & $\begin{array}{l}74.69 \pm \\
0.77\end{array}$ & $\begin{array}{l}86.46 \pm \\
0.25\end{array}$ & $\begin{array}{l}57.87 \pm \\
0.78\end{array}$ & $\begin{array}{l}80.54 \pm \\
0.80\end{array}$ & $\begin{array}{l}63.95 \pm \\
0.66\end{array}$ & $\begin{array}{l}61.78 \pm \\
0.45\end{array}$ & $\begin{array}{l}69.13 \pm \\
0.30\end{array}$ & $\begin{array}{l}56.59 \pm \\
0.47\end{array}$ \\
\hline 24 & $\begin{array}{l}81.78 \pm \\
0.15\end{array}$ & $\begin{array}{l}85.81 \pm \\
0.28\end{array}$ & $\begin{array}{l}74.25 \pm \\
0.51\end{array}$ & $\begin{array}{l}70.41 \pm \\
0.62\end{array}$ & $\begin{array}{l}79.69 \pm \\
0.36\end{array}$ & $\begin{array}{l}77.13 \pm \\
0.18\end{array}$ & $\begin{array}{l}89.72 \pm \\
0.32\end{array}$ & $\begin{array}{l}60.27 \pm \\
0.07\end{array}$ & $\begin{array}{l}83.45 \pm \\
0.64\end{array}$ & $\begin{array}{l}67.79 \pm \\
0.55\end{array}$ & $\begin{array}{l}64.64 \pm \\
0.49\end{array}$ & $\begin{array}{l}73.56 \pm \\
0.66\end{array}$ & $\begin{array}{l}58.75 \pm \\
0.27\end{array}$ \\
\hline
\end{tabular}

${ }^{*}$ Average of three values, ${ }^{ \pm}$Standard deviation

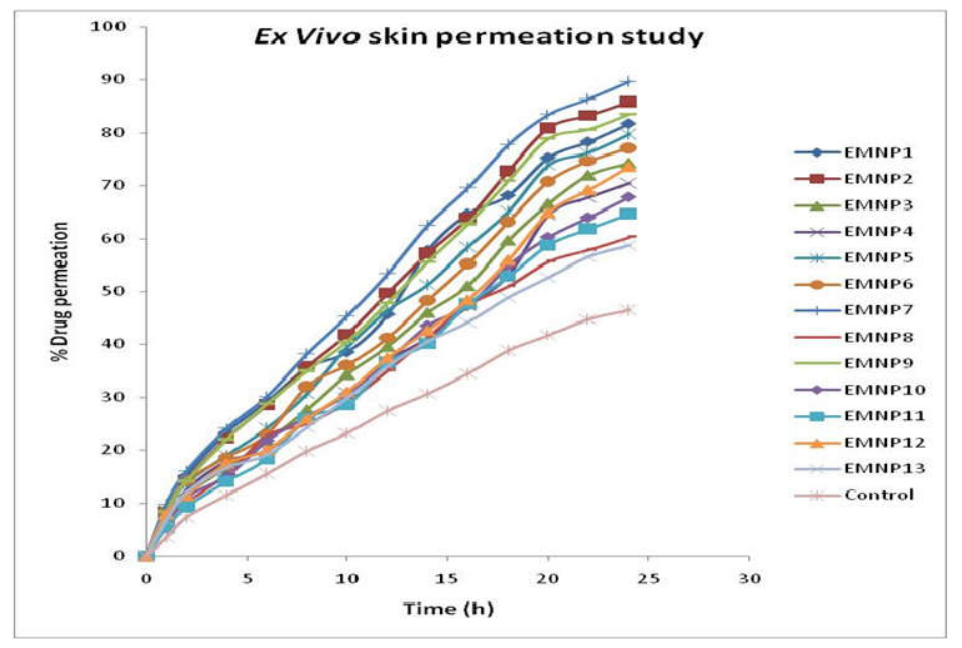

Fig. 10: Ex vivo skin permeation study chart

Table 7: Cumulative percentage and kinetic data obtained from different formulations

\begin{tabular}{|c|c|c|c|c|c|c|}
\hline \multirow{2}{*}{$\begin{array}{l}\text { Formulation } \\
\text { code }\end{array}$} & \multirow{2}{*}{$\begin{array}{l}\text { Percentage of drug permeated } \\
\text { after } 24 \mathrm{~h} \text { from gel }\end{array}$} & \multirow{2}{*}{\begin{tabular}{|l|} 
Zero-order plot \\
Regression \\
\end{tabular}} & \multirow{2}{*}{\begin{tabular}{|l|} 
First-order plot \\
Regression
\end{tabular}} & \multirow{2}{*}{\begin{tabular}{|l|} 
Higuchi plot \\
Regression \\
\end{tabular}} & \multicolumn{2}{|c|}{ Korsmeyer-peppa's plot } \\
\hline & & & & & Slope & Regression \\
\hline EMNP1 & $81.78 \pm 0.15$ & 0.984 & 0.667 & 0.965 & 0.612 & 0.847 \\
\hline EMNP2 & $85.81 \pm 0.28$ & 0.990 & 0.681 & 0.960 & 0.608 & 0.845 \\
\hline EMNP3 & $74.25 \pm 0.51$ & 0.996 & 0.728 & 0.944 & 0.522 & 0.878 \\
\hline EMNP4 & $70.41 \pm 0.62$ & 0.990 & 0.721 & 0.934 & 0.521 & 0.870 \\
\hline EMNP5 & $79.69 \pm 0.36$ & 0.992 & 0.693 & 0.954 & 0.596 & 0.840 \\
\hline EMNP6 & $77.13 \pm 0.18$ & 0.992 & 0.692 & 0.948 & 0.596 & 0.835 \\
\hline EMNP7 & $89.72 \pm 0.32$ & 0.987 & 0.661 & 0.966 & 0.648 & 0.824 \\
\hline EMNP8 & $60.27 \pm 0.07$ & 0.986 & 0705 & 0.965 & 0.524 & 0.866 \\
\hline EMNP9 & $83.45 \pm 0.64$ & 0.989 & 0.679 & 0.961 & 0.607 & 0.843 \\
\hline EMNP10 & $67.79 \pm 0.55$ & 0.995 & 0.722 & 0.952 & 0.517 & 0.874 \\
\hline EMNP11 & $64.64 \pm 0.49$ & 0.994 & 0.748 & 0.948 & 0.566 & 0.900 \\
\hline EMNP12 & $73.56 \pm 0.66$ & 0.993 & 0.723 & 0.930 & 0.554 & 0.849 \\
\hline EMNP13 & $58.75 \pm 0.27$ & 0.987 & 0.688 & 0.968 & 0.550 & 0.845 \\
\hline
\end{tabular}




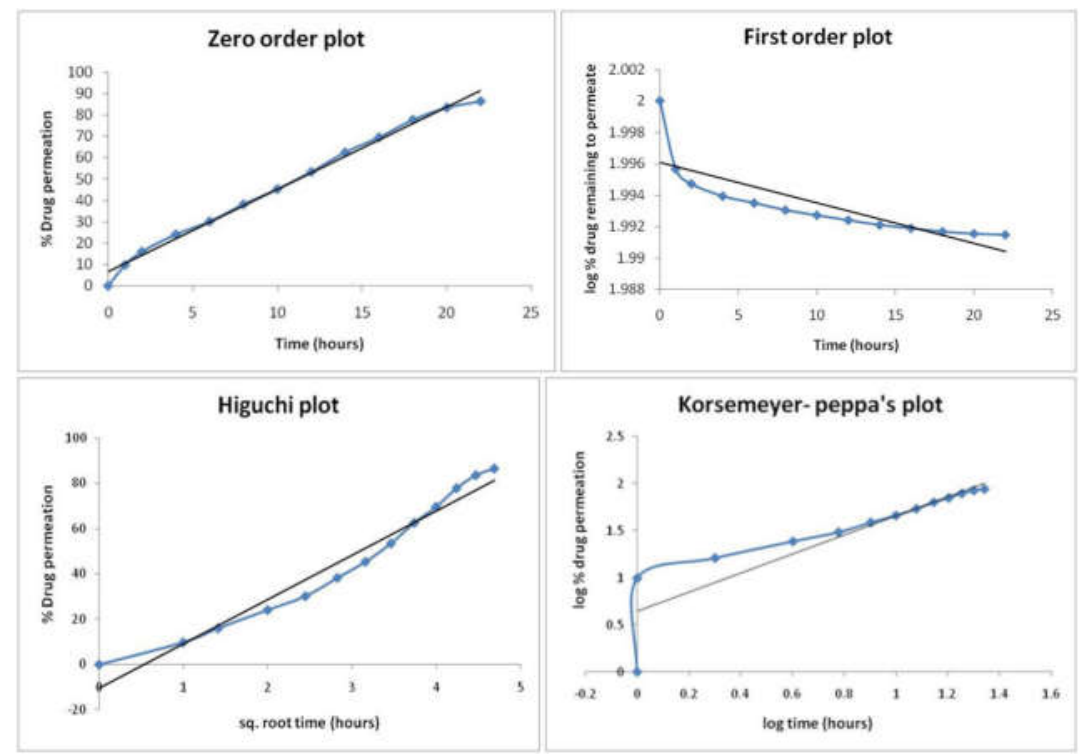

Fig. 11: Kinetic drug release plots of best formulation EMNP7

\section{Release kinetics}

All the formulations from EMNP1 to EMNP13 showed zero-order profile with diffusion, non-fickian release as the possible mechanisms of drug release. From the Higuchi model, the drug permeation was thought to be following the diffusion model. From the Korsmeyer peppa's plot, the drug permeation showed the Nonfickian release. Thus, suggesting that the proniosomal gels could meet the controlled release characteristics. The kinetic data were shown in table 7 and the kinetic drug release plots of the best formulation were shown in fig. 11. The results were in good acceptance with Shanti Sagar et al. (2017) who studied the release kinetics of proniosomal gel of capecitabine [40] and also with Indira $\mathrm{U}$ et al. (2012) who described that in Korsemeyer-peppa's plot, if the release exponent $\mathrm{n}$ value near to 0.5 , then the drug release mechanism is Fickian diffusion and if $\mathrm{n}$ have a value near 1.0 then it is non-Fickian diffusion [4].

\section{Permeation data analysis}

The permeability parameters such as permeation coefficient, flux enhancement ratio were significantly increased in nanoproniosomal formulations. Among them, EMNP7 showed better permeation data than other formulations. The kinetic permeation data was shown in table 8. The results were in good accordance with Faiyaz Shakeel et al. (2007) and Sadashivaiah $\mathrm{R}$ et al. (2008) who studied the permeation data analysis of aceclofenac and haloperidol lactate through transdermal route respectively $[30,31]$.

Table 8: Ex vivo permeation kinetics

\begin{tabular}{lllll}
\hline S. No. & Formulation code & Permeation coefficient $(\mathbf{P})\left(\mathbf{m g} / \mathbf{c m}^{2} / \mathbf{h}\right)^{*}$ & Flux $\left(\mathbf{J}_{\mathbf{s s}}\right)\left(\mathbf{m g} / \mathbf{c m}^{2} / \mathbf{h}\right)^{*}$ & Enhancement ratio $\left(\mathbf{E}_{\mathbf{r}}\right)^{*}$ \\
\hline 1 & Control & 1.21 & 0.242 & - \\
2 & EMNP1 & 2.14 & 0.428 & 0.454 \\
3 & EMNP2 & 2.27 & 0.384 & 1.76 \\
4 & EMNP3 & 1.92 & 0.354 & 1.59 \\
5 & EMNP4 & 1.77 & 0.416 & 1.46 \\
6 & EMNP5 & 2.08 & 0.396 & 1.72 \\
7 & EMNP6 & 1.98 & 0.476 & 1.64 \\
8 & EMNP7 & 2.38 & 0.318 & 1.97 \\
9 & EMNP8 & 1.59 & 0.442 & 1.31 \\
10 & EMNP9 & 2.21 & 0.346 & 1.82 \\
11 & EMNP10 & 1.73 & 0.340 & 1.43 \\
12 & EMNP11 & 1.70 & 0.362 & 1.45 \\
13 & EMNP12 & 1.81 & 0.298 & 1.23 \\
14 & EMNP13 & 1.49 & & \\
\hline
\end{tabular}

Among all formulations, EMNP7 was shown good physicochemical characteristics, better skin permeation, and permeation kinetics Hence, it was selected as the best formulation for further studies such as SEM, zeta potential analysis, skin irritation studies, stability studies, and In vivo antihypertensive studies.

\section{Scanning electron microscopy}

The best formulation EMNP7 was selected for the SEM analysis. It showed good surface morphology. It was shown in fig. 12 .

\section{Vesicle size and zeta potential analysis}

The size of nanoproniosomal gel plays a vital role in drug release; hence it is an important parameter to be determined. The vesicle size and the PI value of the best formulation were determined as $185.2 \mathrm{~nm}$ and 0.492 (which indicates very broad distribution). Zeta potential measurement is very important because it indicates the stability of vesicles. The high value of zeta potential (more than \pm 30 $\mathrm{mV}$ ) shows greater repulsion between charged particles, which reduces aggregation or flocculation and enhances the stabilization of vesicles. The Zeta potential of the best formulation was found to be$84.0 \mathrm{mV}$ and reported as excellent stability. The vesicle size and potential zeta graphs were shown in fig. 13 to 15 . The results were in good accordance with Ali Nasr et al. (2018) who described that particles with zeta potential values more than $(+30 \mathrm{mV})$ or less than $(-30 \mathrm{mV})$ are considered stable and negative values indicate the formation of stable systems [36]. 


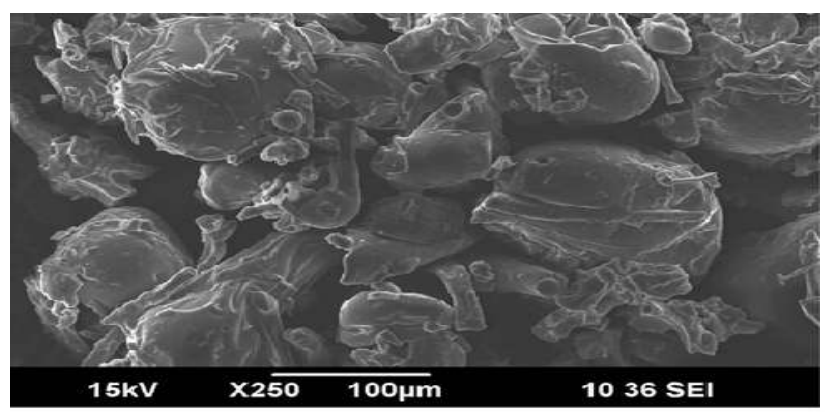

Fig. 12: SEM image of best formulation EMNP7

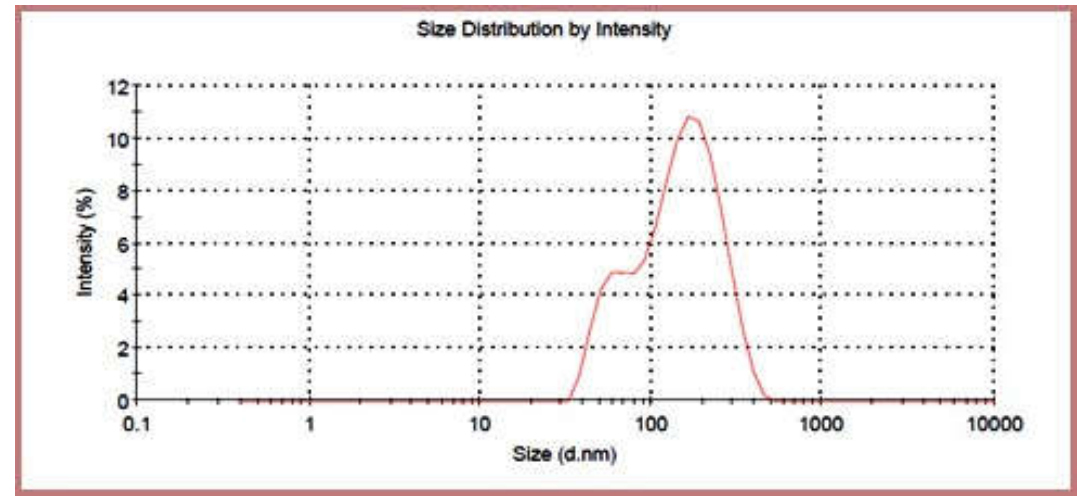

Fig. 13: Vesicle size of nanoproniosomal gel of EM

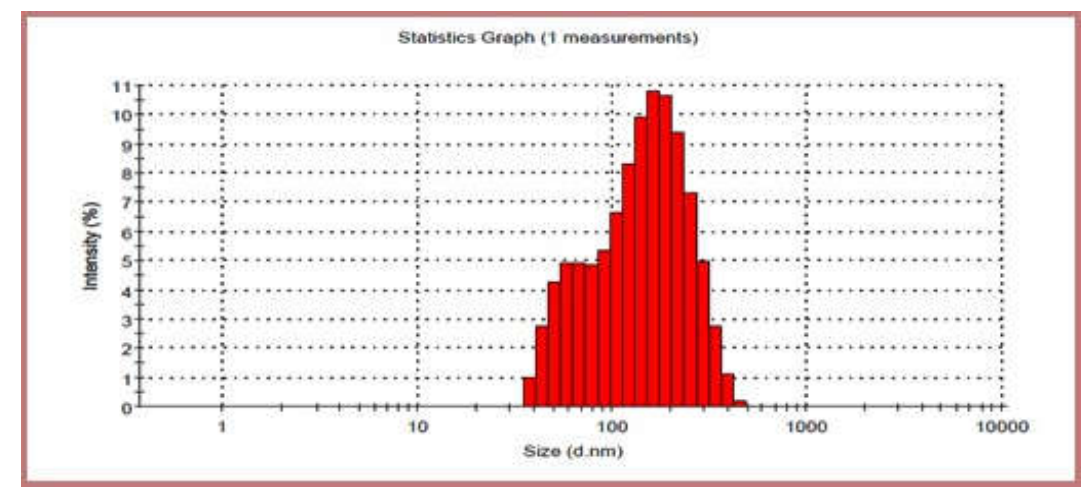

Fig. 14: Vesicle size chart of nanoproniosomal gel of EM

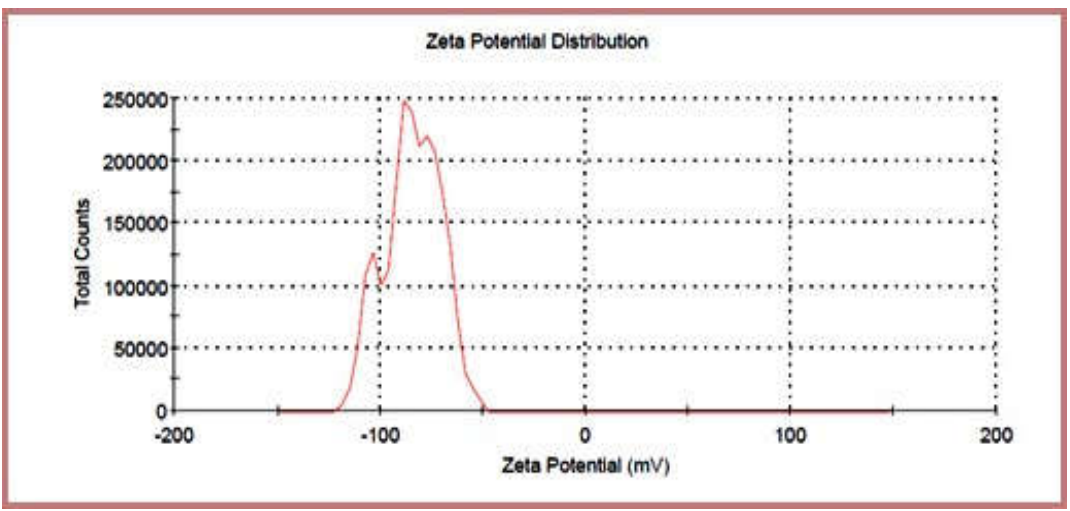

Fig. 15: Zeta-potential of nanoproniosomal gel of EM 

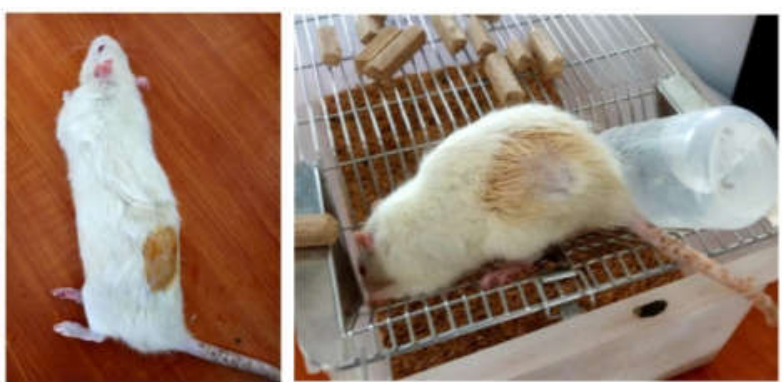

Fig. 16: Skin irritation test of proniosomal gel on albino rat

\section{Skin irritation studies}

The skin irritation test was performed according to OECD guidelines and the results showed no changes like Edema and Erythema. Hence, the formulation passed the skin irritation test and is safe to be used on Human skin. The skin irritation test images were shown in fig. 16.

\section{Stability studies}

Physical appearance and homogeneity were found to be good during the storage period. The Stability studies performed showed that the formulation EMNP7 is highly stable at different temperatures for the prescribed time. Hence, the formulation passed the stability studies. The stability data were shown in table 9. The results were in good accordance with Viney Lather et al. (2016), who performed the stability studies of the proniosomal gel of bromocriptine through transdermal delivery [22].

\section{In vivo antihypertensive studies}

In this study, the normal healthy rats were successfully induced with hypertension by injecting MPA for two weeks and they remained hypertensive for $72 \mathrm{~h}$ after stopping the MPA injection. The Proniosomal gel formulation EMNP7 was found to decrease the BP significantly $(\mathrm{p}<0.001)$ in proximity to the normal value and it was maintained for $24 \mathrm{~h}$ (table 10). This indicates that the drug was permeated and constantly released into the systemic circulation up to $24 \mathrm{~h}$ in rats. However, post-treatment BP values in the treatment group (D) were comparable with the control group (A). On comparing the effects of all the systems, the percentage reduction in mean rat BP by EMNP7 and Placebo EMNP7 was $26.03 \%$ and 0.13 $\%$, respectively (table 10 ). EMNP7 was successful in reverting the rat $\mathrm{BP}$ to normal values. The above results suggest that the formulation EMNP7 holds a promising future for the management of hypertension, which needs to be validated by clinical trials. The results were in good accordance with Abdul Ahad et al. (2014) who investigated the antihypertensive activity of the proniosomal gel of an antihypertensive drug, valsartan for transdermal delivery [37].

Table 9: Stability data

\begin{tabular}{|c|c|c|c|c|}
\hline \multirow[t]{2}{*}{ Storage period } & \multicolumn{4}{|l|}{$4^{\circ} \mathrm{C}^{*}$} \\
\hline & Vesicle size & Entrapment efficiency & Viscosity & pH \\
\hline $15 \mathrm{~d}$ & $5.2 \pm 0.20$ & $84.2 \pm 0.15$ & $10805 \pm 0.72$ & $6.9 \pm 0.16$ \\
\hline $30 \mathrm{~d}$ & $5.1 \pm 0.14$ & $83.9 \pm 0.26$ & $10814 \pm 0.85$ & $6.9 \pm 0.13$ \\
\hline $45 d$ & $5.0 \pm 0.12$ & $82.1 \pm 0.18$ & $10823 \pm 0.76$ & $6.9 \pm 0.25$ \\
\hline \multirow[t]{2}{*}{ Storage period } & $25^{\circ} \mathrm{C}^{*}$ & & & \\
\hline & Vesicle size & Entrapment efficiency & Viscosity & pH \\
\hline $15 \mathrm{~d}$ & $5.2 \pm 0.12$ & $84.8 \pm 0.35$ & $10793 \pm 0.58$ & $6.9 \pm 0.12$ \\
\hline $30 \mathrm{~d}$ & $5.2 \pm 0.21$ & $84.2 \pm 0.22$ & $10801 \pm 0.42$ & $6.9 \pm 0.06$ \\
\hline $45 d$ & $5.0 \pm 0.18$ & $83.4 \pm 0.45$ & $10815 \pm 0.26$ & $6.9 \pm 0.08$ \\
\hline \multirow[t]{2}{*}{ Storage period } & $40^{\circ} \mathrm{C}^{*}$ & & & \\
\hline & Vesicle size & Entrapment efficiency & Viscosity & pH \\
\hline $15 \mathrm{~d}$ & $5.2 \pm 0.06$ & $85.6 \pm 0.28$ & $10781 \pm 0.39$ & $6.9 \pm 0.15$ \\
\hline $30 \mathrm{~d}$ & $5.2 \pm 0.14$ & $85.3 \pm 0.51$ & $10785 \pm 0.46$ & $6.9 \pm 0.23$ \\
\hline $45 d$ & $5.2 \pm 0.23$ & $85.2 \pm 0.48$ & $10788 \pm 0.32$ & $6.9 \pm 0.04$ \\
\hline
\end{tabular}

*Average of three values, ${ }^{ \pm}$Standard deviation

Table 10: Influence of proniosomal gel formulation of EM on mean BP in MPA induced hypertensive rats

\begin{tabular}{llllll}
\hline S. No. & Group & Treatments & \multicolumn{2}{l}{ Mean BP (mm Hg)* } & \% Reduction \\
\cline { 3 - 5 } & & & Pre-treatment & Post-MPA treatment & Post proniosomal gel treatment \\
in BP*
\end{tabular}

${ }^{*}$ Average of six values, ${ }^{ \pm}$Standard deviation

\section{CONCLUSION}

The nanoproniosomal gel of the EM was formulated to improve the bio-availability and permeation of the drug through the skin for the effective treatment of hypertension. Various formulations of the nanoproniosomal gel were prepared by the coacervation phase separation method. Among those formulations, EMNP7 showed better characteristics than other formulations in several aspects like entrapment efficiency, vesicle size, ex vivo permeation studies, skin irritation studies, stability studies, in vivo antihypertensive studies, and other evaluation parameters. Hence, the formulation EMNP7 was selected as the best formulation and is suitable for controlled release once a day formulation. Finally, it could be concluded that the EM loaded nanoproniosomal gel proves to be a beneficial and suitable alternative to the conventional dosage form for the treatment of hypertension.

\section{ACKNOWLEDGMENT}

We are grateful to the Chairman and Principal of Swamy Vivekanandha College of Pharmacy, Tiruchengode and Sree Vidyanikethan College of Pharmacy, Tirupati for providing all the necessary facilities and lab facilities to carry out the research work.

\section{FUNDING}

Nil 


\section{AUTHORS CONTRIBUTIONS}

All the authors have contributed equally.

\section{CONFLICT OF INTERESTS}

Declared none

\section{REFERENCES}

1. Radha GV, Sudha Rani T, Sarwani B. A review on proniosomal drug delivery system for targeted drug action. J Basic Clin Pharm 2013;4:42-8.

2. Jangam Payal R, Thombre Nilima A, Gaikwad Pallavi N. A review: proniosomes as a novel drug delivery system. Asian J Pharm Tech 2017;7:166-74.

3. Srikanth, Anand Kumar Y, Mallikarjuna Setty C. Formulation and evaluation of maltodextrin based doxorubicin $\mathrm{HCl}$ proniosomes. Res J Pharm Technol 2019;12:2776-80.

4. Indira U, Uma Shankar MS. Proniosomes as a drug carrier: a review. Int J Pharm Sci Res 2012;3:4617-25.

5. Venkata Ramesh Yasam, Satya Lavanya Jakki, Jawahar Natarajan, Gowthamarajan Kuppusamy. A review on nove vesicular drug delivery: proniosomes. Drug Delivery 2013;1-7. DOI:10.3109/10717544.2013.841783

6. Swati Mittal, Amit Chaudhary, Anjali Chaudhary, Ankit Kumar. Proniosomes: the effective and efficient drug-carrier system. Ther Delivery 2020. https://doi.org/10.4155/tde-2019-0065

7. Maryam Khatoon, Kiyafat Ullah Shah, Fakhar Ud Din, Shefaat Ullah Shah, Asim Ur Rehman, Naz Dilawar, et al. Proniosomes derived niosomes: recent advancements in drug delivery and targeting. Drug Delivery 2017;24:56-69.

8. Kondawar MS, Kamble KG, Malusare MK, Waghmare JJ, Shah ND. Proniosome based drug delivery system for clotrimazole. Res J Pharm Technol 2011;4:1284-87.

9. Ankur Gupta, Sunil Kumar Prajapati, Bala Murugan M, Mamta Singh, Daksh Bhatia. Design and development of a proniosomal transdermal drug delivery system for captopril. Trop J Pharm Res 2007;6:687-93.

10. Waghmode Maya, Shruthi Ashar. Proniosomal drug delivery systems: an overview. Int J Pharm Chem Sci 2012;1:1044-56.

11. Gopala Krishna Murthy TE, Sai Kishore V. Formulation and evaluation of transdermal gels of diltiazem hydrochloride. Indian J Pharm Educ Res 2008;42:272-6.

12. Sean C Sweetman. Martindale: the complete drug reference. $35^{\text {th }}$ ed. China: Pharmaceutical Press; 2007. p. 1146-8.

13. Medicines compendium. Datapharam Communications Ltd. Great Britain: Vitual Health Network Ltd., and Pharmaceutical Press; 2002. p. 994-7.

14. https://www.drugbank.ca/drugs/DB00584 [Last accessed on 20 Apr 2020]

15. Lokesh BVS, Raghava Naidu S. New dissolution method for the evaluation of enalapril maleate tablets using ph 7.2 phosphate buffer in vitro and determination of its content by validated uv spectrophotometric method. JASA 2007;5:34-7.

16. Simona Gherman, Daniela Zavastin, Adrian Spac, Vasile Dorneanu. Development and validation of UV spectrophotometric method for the determination of enalapril maleate from commercial dosage forms. Farmacia 2015;63:934-7.

17. Ragaa El Sheikh, Ayman A Gouda, Nancy Gouda. Validated spectrophotometric methods for the determination of enalapril maleate in pure and dosage forms. Int J Pharm Pharm Sci 2015;7:190-7.

18. Venkata Ramesh Yasam, Satya Lavanya Jakki, Jawahar Natarajan, Senthil Venkatachalam, Gowthamarajan Kuppusamy, Sumeet Sood, et al. A novel vesicular transdermal delivery of nifedipine-preparation, characterization and in vitro/in vivo evaluation. Drug Delivery 2016;23:619-30

19. Prem Kumar Y, Vinod Kumar K, Sai Kishore V. Preparation and evaluation of diclofenac niosomes by various techniques. Res ] Pharm Technol 2013;6:1097-101.

20. Umekar MJ, Biyani DM, Amgaonkar YM, Bhoyar PK, Lade UB, Kalsait RP. Formulation development and evaluation of transdermal drug delivery system of antihypertensive drug. Res J Pharm Technol 2010;3:753-7.
21. Ming Ming Wen, Ragwa M Farid, Abeer A Kassem. Nanoproniosomes enhancing the transdermal delivery of mefenamic acid. J Liposome Res 2014;24:280-9.

22. Viney Lather, Dharmpal Sharma, Deepti Pandita. Proniosomal gel-mediated transdermal delivery of bromocriptine: in vitro and ex vivo evaluation. J Exp Nanosci 2016;11:1044-57.

23. Soujanya C, Ravi Prakash P. Formulation and evaluation of proniosomal gel-based transdermal delivery of atorvastatin calcium by box-behnken design. Asian J Pharm Clin Res 2019;12:335-43.

24. Khanderao R Jadhav, Ashish Y Pawar, Ashwini A Bachhav, Satish A Ahire. Proniosome: a novel non-ionic provesicules as potential drug carrier. Asian J Pharm 2016;10:S210-22.

25. Nadeem Farooqui, Mousumi Kar, Ravindra Pal Singh. Formulation and development of proniosomal gel for transdermal delivery of ketorolac tromethamine. Asian J Pharm 2016;10:S394-400.

26. Rishu Kakkar, Rao Rekha, Dahiya Navin Kumar, Nanda Sanju. Formulation and characterisation of valsartan proniosomes. Maejo Int J Sci Technol 2011;5:146-58.

27. Ashish Kute, Prakash Goudanavar, Doddayya Hiremath, Reddy SR. Development and characterization of perindopril erbumine loaded proniosomal gel. Asian J Pharm Tech 2012;2:54-8.

28. Amol Shete, Priyanka Thorat, Rajendra Doijad, Sachin Sajane. Formulation and in vitro, in vivo evaluation of proniosomal gel of neomycin sulphate. Int J Appl Pharm 2019;11:156-63.

29. Eman A Mazyed, Sherin Zakaria. Enhancement of dissolution characteristics of clopidogrel bisulphate by proniosomes. Int J Appl Pharm 2019;11:77-85.

30. Faiyaz Shakeel, Sanjula Baboota, Alka Ahuja, Javed Ali, Mohammed Aqil, Sheikh Shafiq. Nanoemulsions as vehicles for transdermal delivery of aceclofenac. AAPS PharmSciTech 2007;8:E1-9.

31. Sadashivaiah R, Dinesh BM, Uma A Patil, Desai BG, Raghu KS. Design and in vitro evaluation of haloperidol lactate transdermal patches containing ethyl cellulose-povidone as film polymers. Asian J Pharm 2008;2:43-9.

32. Sandeep Gupta, Dheeraj Ahirwar, Neeraj K Sharma, Deenanath Jhade. Proniosomal gel as a carrier for improved transderma delivery of griseofulvin: preparation and in vitro characterization. Res J Pharma Dosage Forms Tech 2009;1:33-7.

33. Sharda Sambharkar, Sarvesh Paliwal, Swapnil Sharma, Bishambar Singh. Formulation of risperidone loaded proniosomes for effective transdermal delivery: an in vitro and in vivo study. Bull Fac Pharm (Cairo Univ) 2017;55:239-47.

34. https://www.oecd.org/env/test-no-404-acute-dermalirritation-corrosion-9789264242678-en.htm [Last accessed on 20 Apr 2020]

35. Singh S, Trivedi S, Jain S. Design and development of proniosome based transdermal delivery of ondansetron hydrochloride. Int J Appl Pharm Biol Res 2012;3:191-201.

36. Ali Nasr, Mona Qushawy, Shady Swidan. Spray-dried lactose based proniosomes as stable provesicular drug delivery carriers: screening, formulation, and physicochemical characterization. Int J Appl Pharm 2018;10:125-37.

37. Abdul Ahad, Mohd Aqil, Asgar Ali. Investigation of antihypertensive activity of carbopol valsartan transdermal gel containing 1,8-cineole. Int J Biol Macromol 2014;64:144-9.

38. Ramkanth S, Madhusudhana Chetty C, Sudhakar Y, Thiruvengadarajan VS, Anitha P, Gopinath C. Development, characterization, and in vivo evaluation of proniosomal based transdermal delivery system of atenolol. Future J Pharm Sci 2018;4:80-7.

39. Ankit Acharya, Kiran Kumar GB, Mohammed Gulzar Ahmed, Saroj Paudel. A novel approach to increase the bioavailability of candesartan cilexetil by proniosomal gel formulation: in vitro and in vivo evaluation. Int J Pharm Pharm Sci 2016;8:241-6.

40. Shanti Sagar, Sara Lavanya, Vaishali Sagar, Basavaraj K. Nanjwade. Formulation and evaluation of the proniosomal gel of capecitabine. Indo Am J Pharm Sci 2017;4:2513-20.

41. Ahmed M Samy, Afaf A Ramadan, Amal SM Abu El-Enin, Yasmin IM Mortagi. Formulation and optimization of itraconazole proniosomes using box behnken design. Int J Appl Pharm 2018;10:41-51. 
42. Sunil Kumar, Pushpendra Kumar Jain, Nalini Pandey, Gyanendra Saxena. Comparative study of proniosomal drug delivery system of flurbiprofen. J Chem Pharm Res 2016;8:222-8.

43. Raja K, Jestin Palu Ukken, Athul PV, Tamizharasi S, Siva Kumar $\mathrm{T}$. Formulation and evaluation of maltodextrin based proniosomal drug delivery system containing anti-diabetic (glipizide) drug. Int J PharmTech Res 2011;3:471-7.

44. Radha GV, Trideva Sastri K, Prathyusha P, Bhanu P, Jampala Rajkumar. Formulation and evaluation of aceclofenac proniosome loaded orabase for management of dental pain. Int J Appl Pharm 2018;10:204-10.

45. Prajapati SK, Kumar S, Sahu VK, Prakash G. Proniosomal gel of flurbiprofen: formulation and evaluation. J Drug Delivery Ther 2012;2:1-5.

46. Ashok Mateti, Mohammed Habibuddin, Raju Jukanti. Formulation and evaluation of proniosome based transdermal gel of sumatriptan succinate. Int J Pharm Biol Sci 2016;6:22435 .
47. Hardik A Shah, Disha R Patel, Rakshit N Sonapal, Paresh A Prajapati, Madhabhai M. Formulation and comparative evaluation of transdermal patch and proniosomal gel of ropinirole, an anti parkinson's drug. Int J Pharm Sci Nanotech 2016;9:3091-101.

48. Ameerah A Radhi. Benazepril hydrochloride loaded niosomal formulation for oral delivery: formulation and characterization. Int J Appl Pharm 2018;10:66-70.

49. Didem Ag Seleci, Muharrem Seleci, Johanna Gabriela Walter Frank Stahl, Thomas Scheper. Niosomes as nanoparticular drug carriers: fundamentals and recent applications. J Nanomater 2016;1-13. https://doi.org/10.1155/2016/7372306

50. Rishikesh Gupta, Santosh Kumar, Nikhil Gupta, Anurag Kumar. The new advancement nanotechnology: Proniosomes as a promising and potential drug carrier. Int J Res Dev Pharm Life Sci 2014;3:1258-65.

51. Saroha K, Lauchab A, Kumar D, Verma S, Pratibha, Nanda S Proniosomes: a versatile drug delivery. Int J Res Pharm Pharm Sci 2016;1:43-8. 